\title{
EKG u hrvatskog posavca I lipicanca - frekvencija i ritam
}

\author{
D. Grden, J. Gotić, I. Šmit, M. Crnogaj, N. Brkljača Bottegaro, \\ K. Šimonji, D. Ivšić Škoda, B. Beer Ljubič* i N. Kučer
}

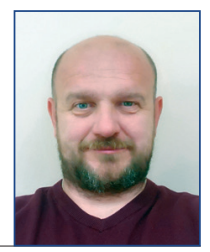

\section{Sažetak}

Cilj istraživanja je bio ustvrditi standardne vrijednosti za frekvenciju srčnog rada i učestalost srčanog aritmija u hrvatskog posavca i lipicanca. U istraživanje su bila uključena 82 zdrava konja, različitog spola i dobi, 32 lipicanca i 50 posavaca. Svim je konjima u baznovršnom odvodu snimljen EKG u trajanju od 5 minuta. Iz snimljenog elektrokardiograma je određena srčana frekvencija, ritam i tip eventualne aritmije. Ustvrđena srednja vrijednost frekvencije $( \pm \mathrm{SD})$ za sve konje uključene $\mathrm{u}$ istraživanje je $52,9( \pm 12,7)$ otkucaja u minuti, što je znatno više od bilo koje od objavljenih vrijednosti za konje do sada. Ustvrđena je učestalost aritmija od 2,4\%. Visoka frekvencija i niska učestalost srčanih artimija mogu biti pasminska karakteristika, ali mišljenja smo da su ove vrijednosti posljedica neprikladnosti primjene ambulantne elektrokardiografije u konja. Smatramo da je za istraživanje elektrokardiografskih karakteristika konja uvijek potrebno životinjama snimiti 24 satni Holter EKG u uobičajenim uvjetima držanja.

Ključne riječi: lipicanac, hrvatski posavac, $E K G$, aritmije, srčana frekvencija

\section{Uvod}

$\mathrm{U}$ veterinarskoj medicini je $\mathrm{u}$ posljednjih nekoliko desetljeća izražen veliki napredak kardiološke dijagnostike, a $\mathrm{u}$ novije vrijeme, $\mathrm{s}$ povećanjem dostupnosti elektrokardiografske opreme i razine znanja kardiologije veterinara praktičara, elektrokardiografska pretraga je postala najraširenija metoda pretrage srca.
Zbog određene specifičnosti u odnosu na pse (kao najčešću vrstu podvrgnutu ovoj dijagnostičkoj metodi u veterinarskoj medicini) u ovom istraživanju željeli smo ustvrditi standardne vrijednosti frekvencije srčanog rada te ustvrditi učestalost fizioloških aritmija za naše najznačajnije pasmine konja; hrvatskog posavca i lipicanca.

Dr. sc. Darko GRDEN*, dr. med. vet., stručni suradnik, dr. sc. Jelena GOTIĆ, dr. med. vet., docentica, dr. sc. Iva ŠMIT, dr. med. vet., docentica, dr. sc. Martina CRNOGAJ, dr. med. vet., docentica, dr. sc. Nika BRKLJAČA BOTTEGARO, dr. med. vet., docentica, Karol ŠIMONJI, dr. med. vet., stručni suradnik, Dora IVŠIĆ ŠKODA, mag. med. biochem., dr. sc. Blanka BEER LJUBIĆ* , (dopisni autor, e-mail: bljubic@vef.hr), dr. sc. Nada KUČER, dr. med. vet., izvanredna profesorica, Veterinarski fakultet Sveučilišta u Zagrebu, Hrvatska 


\section{Elementi elektrokardiograma}

Elektrokardiogram se sastoji od P-QRS-T valova, odnosno zubaca. U konja kompleksi u elektrokardiogramu pokazuju visoku razinu varijabilnosti pa pojedine komplekse u EKG-u definiramo na sljedeći način.

P val predstavlja depolarizaciju atrija, i ima mali otklon od nekoliko milivolta. Normalna morfologija $\mathrm{P}$ vala je vrlo varijabilna. $\mathrm{P}$ val može biti bifidan, (pozitivan i negativan otklon) ili bifazičan (dva odvojena otklona $u$ istom smjeru). Najčešće je amplitude $\mathrm{P}$ vala pozitivna (Menzies-Gow, 2001.).

QRS kompleks je obično veći (do 4 milivolta) i predstavlja depolarizaciju ventrikula. Prvi negativni otklon je Q val, prvi pozitivan otklon je $\mathrm{R}$ val i drugi negativan otklon je $S$ val (Menzies-Gow, 2001.). Zbog ranije opisanog poništavanja valova tijekom depolarizacije komora izgled QRS kompleksa varira od kompletnog QRS-a, do samo S vala.

T val prati QRS kompleks i predstavlja repolarizaciju ventrikula. Vrlo je varijabilan veličinom i orijentacijom, što znači da se morfologija $T$ vala ne može sa sigurnošću koristiti kao indikator srčane bolesti, poremećaja elektrolita ili sistemske bolesti (Menzies-Gow, 2001.). Interpretacija EKG-a vrši se mjerenjem frekvencije QRS kompleksa, analizom ritma te mjerenjem trajanja $i$ visine otklona pojedinih zubaca i valova.

\section{Sustav odvoda i način snimanja elektrokardiograma}

U elektrokardiografiji je potrebno uvijek koristiti isti sistem odvoda, jer ćemo jedino na taj način moći uspoređivati elektrokardiograme iste ili različitih životinja. Bazno vršni odvod (bipolarni odvod čija osovina je gotovo paralelna $\mathrm{s}$ dugom osovinom srca) je najkorisniji sustav odvoda $u$ konja jer su kompleksi koje u njemu bilježimo veliki i lako ih se identificira. U nekim složenijim slučajevima moramo biti spremni snimiti više od samo jednog odvoda kako bismo jasno mogli identificirati komplekse koji nam u bazno-vršnom odvodu nisu bile jasne. Za snimanje EKG-a u konja se uobičajeno koristi baznovršni odvod.

Za snimanje osnovnog EKG-a životinja mora stajati mirno, po mogućnosti na suhom gumenom podlošku, u svrhu izolacije.

Elektrokardiografski uređaji koji se rutinski koriste u kardiologiji konja podešeni su za snimanje Einthovenovih perifernih odvoda (I, II, III, AVr, AVl, AVf) i imaju bojom označene elektrode. Termin odvod odnosi se na standardiziranu kombinaciju elektroda, a ime dobivaju prema mjestu na koje se spajaju. Odvod može biti unipiolaran i bipolaran. Bipolarni odvodi (I, II i III odvod), sastoje se od dva kabla s elektrodom na kraju, jednom pozitivnom i jednom negativnom. Unipolarni odvod dobije se kada se svi kablovi za ekstremitete spoje na negativnu elektrodu elektrokardiografskog uređaja, a preostala prsna elektroda postaje pozitivna elektroda. Većina kliničkih EKG-a snima se bipolarnim sustavom elektroda.

Tradicionalno se EKG u konja snimao koristeći Einthovenov sustav perifernih odvoda (Physick-Sheard, 1999.a), a drugi odvod se koristio za praćenje ritma. Kako je gotovo nemoguće postići da konj cijelo vrijeme stoji mirno za snimanje EKG-a, u konja je puno prikladniji bazno-vršni odvod jer su elementi koje njime bilježimo veći i lakši za očitavanje, a zbog položaja elektroda manje podložni smetnjama od pomicanja životinje.

Bazno vršni odvod se snima tako da pozitivnu elektrodu, elektrodu lijeve ruke (žuta) spojimo na mjesto srčanog apeksa, negativnu elektroda, elektrodu desne ruke (crvena) spajamo na prijelazu sa donje u srednju trećinu jugularnog žlijeba ili na vrh grebena desne lopatice. 
Treća elektroda (crna) se postavlja na bilo koje mjesto udaljeno od srca (ispod grive maksimalno kranijalno na vratu). Bazno vršni odvod se snima u prvom odvodu elektrokardiograma (van Loon i Patteson, 2010.).

Za Y odvod elektrodu desne ruke (crvena) postavljamo na manubrium sterni, a elektroda lijeve ruke (žuta) na ksifoidni izdanak sternuma. Treću elektrodu postavlja se na bilo koje mjesto, što dalje od srca (npr. na vratu ispod grive). Elektrokardiogram se bilježi na elektrokardiografskom uređaju na mjestu prvog odvoda (van Loon i Patteson, 2010.).

EKG se može snimiti u kraćem trajanju, od jedne do nekoliko minuta, kakav obično snimamo tijekom kardiološkog pregleda, ili se može snimiti 24 satni EKG (Holter EKG). Za prethodna snimanja EKG-a životinja treba biti što mirnija, za razliku od snimanja EKG-a pod opterećenjem. kada pomoću Holter uređaja snimamo EKG životinje koja je podvrgnuta fizičkom naporu.

U kratkom elektrokardiogramu uz izgled, amplitudu i trajanje pojedinih kompleksa, možemo identificirati i određene srčane aritmije. Međutim, neke aritmije u tom kratkom vremenu snimanja elektrokardiograma ne moraju biti zabilježene iako smo ih jasno registrirali tijekom kliničkog pregleda ili je životinja anamnestički vrlo suspektna na njih.

Nekoliko je razloga zašto aritmiju nekada ne uspijevamo registrirati pri snimanju ambulantnog EKG-a i najčešće je vezano uz promjenu $u$ tonusu autonomnog živčanog sustava. U tim slučajevima potrebno je snimiti 24 satni Holter EKG u mirovanju ili EKG pod opterećenjem.

Što je trajanje snimanja duže to je snimljeni odsječak reprezentativniji, ali je potrebno i duže vrijeme za obradu, jer se za analizu koriste humani algoritmi, koji nisu baš najtočniji kada su u pitanju konjski elektrokardiogrami (van Loon i Patteson, 2010.).

Elektrokardiogram se snima standardnom brzina papira $(25 \mathrm{~mm} / \mathrm{sec})$ i standardnom osjetljivošću $(10 \mathrm{~mm} / \mathrm{mV})$ radi lakše vizualne usporedbe snimaka. Zbog niske srčane frekvencije u konja potrebno je snimati kontinuirano kroz 1-3 minute zbog što boljeg detektiranja aritmija.

U slučaju kada u elektrokardiogramu nalazimo aritmiju u kojoj je teško očitati jedan ili više valova ili zubaca odlučit ćemo se na snimanje više odvoda da bismo snimanjem $\mathrm{u}$ nekom drugom odvodu ustvrditi nedostaju li zaista određeni valovi i kompleksi.

\section{Analiza elektrokardiograma}

Analizu snimljenog elektrokardiograma moramo vršiti sistematski kako bismo izbjegli eventualne pogreške. Analiza elektrokardiograma vrši se s lijeva na desno, a artefakte treba prepoznati i ne uključiti u analizu.

1. Procjena ritma vrši se prvo provjerom prati li svaki $\mathrm{P}$ val QRS i prethodi li P val svakom QRS-u. Ukoliko je odgovor da, govorimo o sinusnom ritmu; a ukoliko je odgovor ne, govorimo o aritmiji.

2. Izračunavanje frekvencije radimo na odsječku elektrokardiograma u trajanju 6 sekundi, u kojem se odredi broj $R$ valova $i$ dobivena vrijednost pomnoži s 10.

3. Analiza i mjerenje pojedinih kompleksa podrazumijeva određivanje visine i širine $P$ vala, trajanje $P-R$ intervala, trajanje $Q R S-a$ i visinu $R$ vala te trajanje Q-T intervala.

\section{Frekvencija}

Srčana frekvencija se $\mathrm{u}$ zdravih odraslih konja kreće od 28 do 40 u minuti. U ždrebnih kobila frekvencija se u posljednjem mjesecu graviditeta kreće oko 60 akcija u minuti, a neposredno pred porod frekvencija raste do $80 \mathrm{u}$ minuti. U ždrjebadi se frekvencija kreće 
od maksimalnih $100 \mathrm{u}$ minuti 48 sati nakon porođaja i nakon toga postupno pada da bi se u dobi od 5 mjeseci spustila na razinu odraslih konja (PhysickSheard, 1999.c). Frekvencija veća ili manja od fizioloških vrijednosti (raspon 20-160 akcija u minuti) se često susreće u konja, ali je vrlo rijetko indikator kardiovaskularne bolesti.

Tahikardija. Frekvencija srčanog rada je pod direktnim utjecajem autonomnog živčanog sustava, humoralnih faktora i tjelesne temperature; oni direktno utječu na brzinu otpuštanja impulsa iz srčanih pacemakera (Guyton, 2006.). Glavni čimbenici koji preko prethodno spomenutih mehanizama dovode do promjena $u$ srčanoj frekvenciji su promjene $\mathrm{u}$ krvnom tlaku te uzbuđenje. Povećanje srčane frekvencije, tahikardija, odraz je povećane potrebe za srčanim volumenom, smanjenog kapaciteta srca koje ne može podmiriti potrebe organa u mirovanju i aritmija. U svim slučajevima znatnog povećanja frekvencije potrebno je snimiti EKG kako bi se potvrdilo sinusno podrijetlo tahikardije, imajući na umu da sinusna tahikardija u bolesnih životinje rijetko prelazi preko 120 udaraca u minuti, a u zdravih konja sinusni tahikardija može biti i do 160 udaraca u minuti (Physick-Sheard, 1999.c).

Bradikardija. Ona može biti relativna ili apsolutna, a javlja se vrlo rijetko u odraslih konja, a povremenu nalazimo u ždrjebadi. Apsolutna se bradikardija javlja $\mathrm{u}$ odraslih konja najčešće vezana uz AV blok trećeg stupnja pri čemu frekvencija padne na 12 do 16 udaraca $\mathrm{u}$ minuti (mogu se javiti i sinkope). U zdravih starijih trkaćih konja možemo naći relativnu bradikardiju (frekvencija 24 do 28 udaraca u minuti). Bradikardija se javlja u hipoglikemične ždrjebadi i $\mathrm{u}$ vezi s hiperkalijemijom, povećanim intrakranijalnim pritiskom i stimulacijom vagusa. U svim slučajevima bradikardije potrebno je snimiti i EKG (PhysickSheard, 1999.a).

\section{Ritam}

Termin disritmija i aritmija se često puta koriste kao sinonimi, međutim $\mathrm{u}$ pravom smislu disritmija je poremećaj ritma, a aritmija izostanak ritma (Kruz i sur., 2000.).

\section{Podjela aritmija}

U literaturi se može susresti više različitih podjela aritmije. Tako, prema mjestu nastanka aritmije mogu biti: atrijske (nastale u pretklijetkama) i ventrikulske (nastale u klijetkama); zatim se mogu podijeliti na smetnje u stvaranju podražaja, provođenja podražaja i ektopične aritmije koje nastaju izvan sinusnog čvora. Prema brzini srčanog ritma mogu se podijeliti na tahiaritmije (ubrzani ritam) i bradiaritmije (usporeni srčani ritam). Dobar dio aritmija u konja smatramo fiziološkima, a za aritmiju ukoliko tijekom napora $u$ potpunosti nestane kažemo da je fiziološka.

Etiologija fizioloških aritmija povezana je s homeostazom krvnog tlaka $\mathrm{u}$ konja koja se u životinja u mirovanju odražava promjenama $u$ tonusu parasimpatikusa (Hamlin i sur., 1972.). Povećanje tonusa vagusa, u kontroli arterijskog pritiska, rezultira nastankom provodnog bloka u sinusnom i AV čvoru, što za posljedicu ima veliku učestalost vagusom induciranih iregularnosti $u$ srčanog ritma u mirovanju kod zdravih konja (Holmes i Alps, 1966., Raekalio, 1992.).

SA i AV čvor su mjesta najosjetljivija na (fiziološke) funkcionalne blokove, jer je brzina provođenja impulsa najviše ovisna u struji kalcijevih kanala (Nattel i sur., 2007.), a povećanje tonusa vagusa inhibira otvaranje kalcijevih kanala i smanjuje brzinu prolaska električnog impulsa. Funkcionalni blokovi koji rezultiraju aritmijama su česti u konja zbog visokog tonusa vagusa.

Najčešće promjene $u$ ritmu prouzročene vagotonijom su: sinusna bradikardija, sinusna aritmija, 
atrioventrikularni blok prvog i drugog stupnja. Ukoliko ove aritmije tijekom rada nestaju ne smatramo ih uzrokom smanjene radne sposobnosti (Marr, 1997.)

Smanjena radna sposobnost može biti prouzročena fibrilacijom atrija, potpunim srčanim blokom te preuranjenim atrijskim i ventrikularnim kontrakcijama (Holmes, 1974.).

\section{Sinusna aritmija}

To je termin koji se $\mathrm{u}$ veterinarskoj medicini koristi za opisivanje. vagusom izazvane aritmije povezane $\mathrm{s}$ disanjem (respiratorna sinusna aritmija), aritmije uslijed napora (sinusna aritmija vezana uz napor) i varijacije $\mathrm{u} R-\mathrm{R}$ intervalima koje se najčešće povezuju $\mathrm{s}$ djelomičnim AV blokom drugog stupnja.

Sinusna aritmija se vrlo rijetko javlja u mirovanju, ali je često puta zabilježena u vrijeme oporavka nakon rada kada dolazi do promjene iz simpatičkog $u$ parasimpatički tonus (Patteson, 1996.).

Sinusna aritmija vezana uz napor je potpuno normalna (Glending, 1972. Rezakhani, 1975., Holmes, 1980.), a manifestira se $\mathrm{u}$ utreniranih konja $\mathrm{u}$ vrlo laganom i kratkom radu i očituje se naglim usporavanjem frekvencije srčanog rada nakon čega slijedi njeno postupno povećanje.

Sinusna aritmija se često opisuje kao pratitelj AV bloka drugog stupnja (Broijmans, 1957., Watsabaugh i sur., 1964.) mada nikada nije ustvrdena njihova međusobna povezanost (Watsabaugh i sur., 1964.). Varijacije u R-R intervalima koje često nalazimo uz djelomični AV blok drugog stupnja treba smatrati nerespiratornom sinusnom aritmijom (Watsabaugh, 1963.). Smatra se da je usporenje sinusnog ritma prouzročeno refleksnom inhibicijom SA čvora kroz luk aorte i refleks karotidnog sinusa.

Lutanje centra vodiča je elektrokardiografska dijagnoza koja se postavlja na osnovu ustvrđenih varijacija $\mathrm{u}$ izgledu $\mathrm{P}$ vala, a smatra se da je odraz varijacija u lokaciji centra vodiča ili unutar samog SA čvora ili unutar stjenke cijelog atrija. Ovaj nalaz je uobičajen u konja, posebice u utreniranih životinja, a aritmija se smatra benignom (Holmes, 1984.).

\section{Sinusatrijski blok i sinusni arest}

Sinusatrijski blok se u pravilu smatra benignom vagusom induciranom aritmijom koja se $\mathrm{u}$ konja javlja relativno rijetko (Vibe-Petersen i Nielsen, 1980.), međutimnekiautori ovu aritmiju smatraju patološkom (Kiryu i sur., 1985.). Smatra se da je aritmija benigna ukoliko životinja $\mathrm{u}$ mirovanju ima normalnu frekvenciju srca, a aritmija nestane $u$ laganom radu ili uzbuđenju. Razlika između bloka i aresta je gotovo $\mathrm{u}$ potpunosti akademska jer nije razjašnjeno da li impuls nastane ali ne bude otpušten iz čvora ili je spriječeno njegovo formiranje. U konja povišen tonus vagusa puno češće rezultira odgođenim provodom impulsa kroz AV čvor nego što prouzroči sinusnu bradikardiju.

Sinusatrijski blok karakterizira normalna ritam $\mathrm{s}$ povremenim ispuštenim udarcima, kada u EKG-u nalazimo ,električnu tišinu”, odnosno nema niti P vala niti QRS-T kompleksa. U elektrokardiogramu nalazimo dužu pauzu između normalnih kompleksa. Kada je propušten jedan udarac P-P interval u kojem je ispušten udarac je duplo veći nego normalni P-P intervali $\mathrm{u}$ tom elektrokardiogramu, ali ovo pravilo nije isključivo (Holmes, 1980.). Sinusni arest se u elektrokardiogramu manifestira isto kao i sinoatrijski blok uz razliku u trajanju P-P intervala između kojih je propušten udarac koji u su u ovom slučaju duži.

\section{Atrioventrikularni (AV) blok}

AV blok se definira kao abnormalan mehanizam u kojem dolazi do kašnjenja ili izostanka ventrikularnih depolarizacija. AV blok smo podijelili na djelomični AV blok I. stupnja, djelomični 
AV blok II stupnja, potpuni AV blok III stupnja. Učestalost ovih blokova se ovisno o autorima kreće od $6,4 \%$ do $40 \%$ (Broijmans, 1957., Holmes,1963., Buchan, 1965., Holmes i Alps, 1966., 1969., Beglinger i sur., 1980., Holmes, 1980., Vibe-Petersen i Nielsen, 1980.), s većom učestalošću AV bloka II stupnja nego AV bloka prvog stupnja.

Djelomični AV blok I. stupnja. Vrijeme atrioventrikularnog provođenja impulsa je produženo, ali u konačnici svi impulsi budu provedeni do ventrikula, a frekvencija je obično normalna ili niska (Holmes i Alps, 1966.). Kod iste životinje često puta možemo naći AV blok I. i AV blok II. stupnja. U konja su varijacije $\mathrm{u}$ P-R intervalu toliko učestale da je teško definirati AV blok I. stupnja.

Djelomični AV blok drugog stupnja. Neki od atrijskih impulsa ne budu provedeni do ventrikula, koji se uslijed toga ne kontrahiraju (Holmes i Alps, 1966.). AV blok drugog stupnja nalazimo u $20 \%$ konja u mirovanju, a vjerojatno je i češći $\mathrm{u}$ životinja koje su u potpunosti na miru (Patteson, 1996.).

Djelomični AV blok drugog stupnja može nastati kada arterijski krvni tlak naraste do određene razine (Miller i Holmes, 1983.). Blokiranjem udarca dolazi do redukcije arterijskog tlaka, nakon čega uslijedi postupni porast arterijskog tlaka sa svakim sljedećim udarcem dok ne bude postignuta maksimalna razina krvnog tlaka i AV blok drugog stupnja se ponovi. Ovaj efekt "stepenica" je uobičajeni homeostatski mehanizam kontrole krvnog tlaka.

Djelomični AV blok drugog stupnja se dijeli na dva tipa: tip 1 (ili Weckenbach) i tip 2 (Physick-Sheard, 1999.b).

Blok tipa 1 je najčešći u konja a karakterizira ga progresivno produljenje PR intervala prije blokiranog $\mathrm{P}$ vala (Holmes i Alps, 1966.), nakon blokiranog $\mathrm{P}$ vala uslijedi skraćenje P-R intervala, međutim vrlo često najdulji P-R intervali slijedi u prvom ili drugom udarcu nakon bloka (Watsabaugh, 1963.). Atriji prate ovaj način usporavanja čime se zapravo radi o sinusnoj aritmiji, za koju smo ranije rekli da prati djelomični AV blok II. stupnja.

Kod tipa II do blokade P vala dolazi bez produljenja intervala, a ovaj je oblik u konja rijedak (Holmes i Alps, 1966.).

Najčešće bude blokiran jedan P val, a blokada se obično ponavlja nakon nekoliko normalnih srčanih ciklusa ali nekad može biti blokirano i nekoliko uzastopnih P valova.

Ova fiziološka aritmija treba biti zamijenjena sinusnom tahikardijom u uzbuđenju, radu i nakon aplikacije vagolitičnih preparata (Reef i Marr, 2010.) Smatra da je aritmija benigna ukoliko u radu ili uzbuđenju nestane i ne pojavi se dok srčana frekvencija ne dođe na fiziološku razinu.

AV blok III stupnja. Atrijski impulsu budu u potpunosti zaustavljeni, odnosno niti jedan impuls ne bude proveden do ventrikula. Ventrikule tada kontrolira idioventrikularni centar vodiča (Holmes i Alps, 1966.). Ovaj blok je rijedak u konja, a točan uzrok njegovoj pojavi je vrlo rijetko identificiran, a najčešće ga se povezuje s upalnim i degenerativnim promjenama u AV čvoru (Reef i sur., 1986.). Atriji i ventrikuli rade odvojeno jedan od drugoga, atriji sinusnom frekvencijom između 28 i 40 akcija u minuti, a ventrikuli idioventrikularni ritmom od 10 do 20 akcija u minuti. U EKG-u obično nalazimo $\mathrm{P}$ valove koji nisu popraćeni QRS kompleksom (nema dokaza AV provodnosti), i QRS komplekse koji su prošireni i bizarnog izgleda, jer potječu iz idoventrikularnog pacemakera. Ako su QRS kompleksi pravilno razmaknuti svi trebaju biti međusobno slični, jer potječu iz istog idoventrikularnog pacemakera. Ovo su poznati „escape" kompleksi jer predstavljaju nastojanje ventrikula da pobjegne $\mathrm{u}$ nedostatku AV provođenja. Ukoliko je prisutna i ektopija naći ćemo 
više od jednog QRS kompleksa, a R-R interval može varirati. P-R interval će biti varijabilne duljine bez konzistentne veze između P vala i QRS kompleksa i puno je više $\mathrm{P}$ valova nego QRS kompleksa (Reef i Marr, 2010.).

Izgled QRS kompleksa varira, u slučajevima u kojima je ventrikularni centar vodič smješten unutar provodnog sustava QRS je normalan, a ukoliko je centar izvan provodnog sistema QRS će biti proširen, a može biti i bizarnog oblika. Ovaj blok može biti kontinuiran i intermitentan. Konji s AV blokom III. stupnja će imati učestale sinkope i znakove netoleriranja rada.

\section{Fibrilacija atrija}

Fibrilacija atrija je najčešća aritmija od kliničkog značenja u konja, učestalost se ovisno o autorima kreće od 0,34\% do 2,5 \% (Holmes, 1969., Else i Holmes, 1971., Deem i Fregin, 1982.). Bolest je dokazana u konja neovisno o pasmini, spolu i dobi, a u konja ju je prvi puta zabilježio Lewis 1911. godine. Različiti autori su ustvrdili različite učestalosti u određenih pasmina konja pa tako iznose veću učestalost fibrilacije atrija $u$ teških pasmina konja te u starijih životinja (Holmes, 1969., Else i Holmes, 1971.); s druge strane neki autori iznose najveću učestalost fibrilacije atrija engleskih punokrvnjaka i američkih kasača (Deem i Fregin, 1982.).

Bolest se može liječiti u životinja koje nemaju ili imaju blagu srčanu bolest te se postići $100 \%$ izlječenje te puna radna sposobnost životinje. U konja s postojećom srčanom bolesti liječenje ima minimalan učinak na prognozu bolesti, a u nekim slučajevima može biti i opasno.

U EKG-u nalazimo nepravilno nepravilne $\mathrm{R}-\mathrm{R}$ intervale, $\mathrm{P}$ vala nema, a QRS kompleks izgleda normalno. Brzi izoelektrični "f" valovi su obično prisutni, a mogu biti niski ili visoki. U otprilike $10 \%$ konja s fibrilacijom atrija nalazimo i QRS komplekse koji potječu iz ventrikula, a u slučaju kongestivnog zatajenja srca nalazimo tahikardiju.

Paroksizmalna fibrilacija atrija je oblik bolesti koji se najčešće javlja u zdravih konja. Kod paroksizmalne atrijske fibrilacije dolazi do spontane pojave i nestanka aritmije (Reef i Marr, 2010.). Ova se aritmija opisuje kao vježbom inducirana aritmiju koja spontano nastaje tijekom rada, što se manifestira u naglom umoru tijekom rada i spontano, nakon nekoliko minuta ili nekoliko dana, nestaje (Amada i Kurita, 1975., Ohmura i sur., 2003.).

\section{Preuranjene atrijske kontrakcije}

Ova je bolest vrlo neuobičajena u konja i klinički od malog značenja. Ektopička aktivnost $\mathrm{u}$ stjenci atrija dovodi atrijskih ekstrasistola. U EKG-u nalazimo kratak P-P interval i promjenu u obliku P vala, ali je potreban oprez kod postavljanja ove dijagnoze jer je kombinacija lutajućeg centra vodiča i sinusne aritmije sličnog izgleda u elektrokardiogramu. Izgled QRS kompleksa u EKG-u je u pravilu normalan.

\section{Ventrikularne preuranjene kontrakcije}

Ventrikularne preuranjene kontrakcije su su vrlo česte u konja, a javljaju se vezano uz bolesti miokarda, ali jednako tako se mogu javiti i bez srčane bolesti. Ukoliko se radi o rijetkim ekstrasistolama, bez srčane bolesti, čija se učestalost u radu ne povećava, a ostali QRS kompleksi u EKG-u su normalni, možemo ih smatrati klinički nebitnima (Holmes, 1980.) za razliku od slučajeva u kojima nalazimo učestale ekstrasistole i varijabilne QRS komplekse te ih se redovito povezuje sa srčanom bolesti.

Na EKG-u se ventrikularne preuranjene depolarizacije očituju u vidu promijenjenog QRS kompleksa kojemu ne prethodi P val. Najčešće se javlja u obliku širokog QRS kompleksa kojeg prati T val okrenut u suprotnom smjeru. 
Ako ventrikularne preuranjene depolarizacije imaju istu konfiguraciju opisujemo ih kao monomorfne dok ventrikularne preuranjene depolarizacije $s$ više od jedne konfiguracije opisujemo kao polimorfne, što implicira na njihovo podrijetlo $s$ više od jednog mjesta $u$ ventrikulima.

Rijetke ventrikularne preuranjene depolarizacije zabilježene su u mirovanju te za vrijeme i nakon rada kod zdravih konja, ali ukoliko su ventrikularne preuranjene kontrakcije učestale i polimorfne smatramo ih patološkima. Potencijalni uzroci uključuju miokarditis, degeneraciju, nekrozu ili fibrozu, disbalans elektrolita, hipooksiju i endotoksemiju (Reef i Marr, 2010.).

\section{Ventrikularna tahikardija}

U konja je opisana paroksizmalna i permanentna ventrikulatrna tahikardija (Broijmans, 1957., Too, 1960., Glazier i Dukes, 1963.). Aritmija se javlja kada upravljanje srčanim radom preuzme nenormalan ventrikuski fokus. Frekvencija je visoka, redovito preko 100 akcija u minuti. Ukoliko stanje perzistira može doći do trajnog oštećenja miokarda. Liječi se antiaritmicima. Paroksizmalne ventrikularne tahikardije nastaju spontano s naglim nastupom i nestankom aritmije.

EKG je bitan u prosuđivanju značenja porasta frekvencije $u$ prosudbi ventrikularne tahikardije. Izgled QRS kompleksa i T vala je promijenjen i QRS kompleks je nepovezan s P valom kojemu prethodi. P-P interval je pravilan, ali su $\mathrm{P}$ valovi često sakriveni u $\mathrm{T}$ valu ili $\mathrm{QRS}$ kompleksu i T valu (atrioventrikularna disocijacija).

Monomorfna ventrikularna tahikardija se javlja kada je fokus iz kojeg potječu ektopični podražaji samo na jednom mjestu $u$ ventrikulu, čime nastaje samo jedan abnormalni QRS kompleks izgled T vala, a obični i R-R interval su pravilni.
Polimorfna ventrikularna tahikardija se javlja kada ventrikularna preuranjena depolarizacija potječe iz više od jednog fokusa u ventrikulu, a takvi QRS kompleksi i T valovi su abnormalni, različite orijentacije. Polimorfne ventrikularne preuranjene kontrakcije povezuju se s električnom neravnotežom i nestabilnošću, a posljedično postoji povećana opasnost od razvoja fatalne ventrikularne aritmije.

Fenomen R preko $\mathrm{T}$ kod kojeg se QRS kompleks javlja unutar prethodnog $\mathrm{T}$ vala također je indikator znatnog električnog disbalansa i povećava rizik od ventrikularne fibrilacije. Tahikardija sa širokim QRS kompleksima ili torsade de pointes u kojoj se QRS kompleks i $\mathrm{T}$ val zakreću oko izoelektrične linije je još jedan oblik ventrikularnog ritma koji može brzo prijeći u ventrikularnu fibrilaciju i rezultirati naglom smrću (Reef i Marr, 2010.).

\section{Fibrilacija ventrikula}

Fibrilacija ventrikula je terminalna aritmija, javlja se neposredno pred smrt, i njeno prepoznavanje je bitno zbog poduzimanja hitne pomoći $u$ vidu električne defibrilacije. Električna defibrilacija je opisana kod konja (Witzel i sur., 1968.), ali redovito nije izvediva.

U EKG-u nalazimo grube undulacije oko izoelektrične linije, frekvencija je niska, a uobičajeni elektrokardiografski kompleksi nisu prepoznatljivi (Reef i Marr, 2010.).

\section{Blok grane}

Do bloka grane dolazi kada je prekinuto provođenje signala kroz ventrikularni provodni sustav, najčešće ljekovima, upalnom ili degenerativnom bolesti miokarda (Physick-Sheard, 1999.b). Depolarizacija ide kroz miokard, a ne kroz specijalizirana vlakna. Rezultat joj je bizarni produženi QRS. Jasni kriteriji za elektrokardiografsku dijagnostiku nisu postavljeni. 


\section{Materijali i metode}

\section{Klinička obrada}

$\mathrm{U}$ ovo istraživanje uključene su dvije pasmine konja; hrvatski posavac s područja veterinarske ambulante „Križ kao predstavnik skupine hladnokrvnih konja te konji lipicanske pasmine s Državne ergele Lipik te Državne ergele Đakovo kao predstavnici toplokrvne pasmine konja. U istraživanje je bilo uključeno 50 konja različite dobi i spola pasmine hrvatski posavac te 32 konja različite dobi i spola lipicanske pasmine. Konji su podijeljeni $u$ dvije podskupine po spolu te u 3 podskupine po dobi.

Sve životinje su prije uključivanja u istraživanje detaljno klinički pregledane kako bi se potvrdilo da su zdrave. U istraživanje su uključeni samo zdravi konji. Svim konjima uključenim $u$ istraživanje učinjena je klinička pretraga kardiovaskularnog sustava te im je nakon toga snimljen elektrokardiogram.

\section{Elektrokardiografska pretraga}

Svim konjima snimljen je EKG $u$ trajanju od 5 minuta. EKG je snimljen u baznovršnom odvodu kod kojeg je pozitivna elektroda LA (žuta) postavljana na grudnu stijenku s lijeve strane, odmah iza lakatne kvrge, a negativna elektroda RA (crvena) $u$ desni jugularni žlijeb, na prijelazu iz donje $u$ srednju trećinu desnog jugularnog žlijeba. Treća elektroda LL (crna) postavlja se na vratu, što dalje od srca, obično ispod grive. Životinje su za vrijeme snimanja stajale na suhoj podlozi. EKG je snimljen na uređaju
Ascard Mr. Silver (Aspel S.A. Czech Republic) s osjetljivošću od $10 \mathrm{~mm} / 1 \mathrm{mV}$ te brzinom od $25 \mathrm{~mm} / \mathrm{s}$.

\section{Statistička obrada}

Statistička obrada uključuje deskriptivnu parametrijsku obradu podataka, a t-test je korišten za usporedbu srednjih vrijednosti skupina odvojenih po pasminama, spolu i dobi. Statistička analiza učinjena je na računalnom programu "Statistica 9".

Ovo istraživanje odobreno je odlukom Etičkog povjerenstvo Veterinarskog fakulteta Sveučilišta u Zagrebu koja je potvrđena na 33. redovitoj sjednici fakultetskog vijeća, 22. listopada 2010.

\section{Rezultati}

\section{Srčani ritam}

Analizom srčanog ritma ustvrđeno je da je ritam u 80 životinja (97,5 \%) pravilan dok je u 2 životinje bio nepravilan. U dva konja u kojih je ustvrđena aritmija nađene su: fibrilacija atrija u jednog konja posavske pasmine $\mathrm{i}$ atrioventrikularni blok drugog stupnja u jednog lipicanca (Tabela 1).

\section{Srčana frekvencija}

$\mathrm{Za}$ srčanu frekvenciju je iz individualnih mjerenja napravljena deskriptivna statistička obrada te je prikazana srednja vrijednost, standardna devijacija, minimum i maksimum za sve konje zajedno, zatim za svaku pasminu odvojeno te nakon toga za pojedine podskupine (prema spolu i dobi). Rezultati navedenih statističkih analiza prikazani su u tabelama 2 i 3 .

Tabela 1. Srčani ritam u svih svih životinja uključenih u istraživanje podijeljenih prema pasmini.

\begin{tabular}{|l|c|c|c|}
\hline & SINUSNI RITAM & FIBRILACIJA ATRIJA & AV BLOK II STUPNJA \\
\hline SVI KONJI & 80 & 1 & 1 \\
\hline POSAVCI & 49 & 1 & 1 \\
\hline LIPICANCI & 31 & & 1 \\
\hline
\end{tabular}


Tabela 2. Srčana frekvencija svih životinja uključenih u istraživanje te podijeljenih prema pasmini i spolu.

\begin{tabular}{|l|c|c|c|c|c|c|c|c|c|}
\hline & \multicolumn{3}{|c|}{ SVI KONJI } & \multicolumn{3}{c|}{ POSAVCI } & \multicolumn{3}{c|}{ LIPICANCI } \\
\cline { 2 - 12 } & SVI & M & $\check{Z}$ & SVI & M & $\check{Z}$ & SVI & M & $\check{Z}$ \\
\hline \begin{tabular}{l} 
BROJ KONJA \\
\hline $\begin{array}{l}\text { SREDNJA } \\
\text { VRIJEDNOST }\end{array}$
\end{tabular} & 52 & 34 & 48 & 50 & 14 & 36 & 32 & 20 & 12 \\
\hline $\begin{array}{l}\text { STANDARDNA } \\
\text { DEVIJACIJA }\end{array}$ & 12,73 & 13,11 & 11,96 & 13,33 & 15,62 & 12,36 & 11,65 & 11,29 & 11,19 \\
\hline \begin{tabular}{l} 
MINIMUM \\
\hline MAKSIMUM
\end{tabular} & 28 & 28 & 30 & 28 & 28 & 30 & 34 & 34 & 42 \\
\hline
\end{tabular}

Tabela 3. Srčana frekvencija u konja podjeljenih u tri dobne skupine, iskazana prema pasminama

\begin{tabular}{|l|c|c|c|c|c|c|}
\hline & \multicolumn{3}{|c|}{ POSAVCI } & \multicolumn{3}{c|}{ LIPICANCI } \\
\cline { 2 - 8 } & $\mathbf{1 - 4 g o d i n e}$ & $\mathbf{5 - 9 g o d i n a ~}$ & $\begin{array}{c}\boldsymbol{>} \\
\text { 9godina }\end{array}$ & $\mathbf{1 - 4 g o d i n e}$ & $\begin{array}{c}\mathbf{5 - 9} \\
\text { godina }\end{array}$ & $\begin{array}{c}\mathbf{9} \\
\text { godina }\end{array}$ \\
\hline BROJ KONJA & 27 & 14 & 9 & $/$ & 15 & 17 \\
\hline $\begin{array}{l}\text { SREDNJA } \\
\text { VRIJEDNOST }\end{array}$ & 57,74 & 50,14286 & 49,78 & $/$ & 48,27 & 53,18 \\
\hline $\begin{array}{l}\text { STANDARDNA } \\
\text { DEVIJACIJA }\end{array}$ & 12,55 & 14,43 & 12,02 & $/$ & 9,03 & 13,40 \\
\hline MINIMUM & 36 & 28 & 30 & $/$ & 36 & 34 \\
\hline MAKSIMUM & 90 & 72 & 64 & $/$ & 76 & 72 \\
\hline
\end{tabular}

\section{Rasprava i zaključak}

Učestalost aritmija $u$ hrvatskih pasmina konja je izrazito niska, aritmije su utvrđene samo u dvije životinje što je učestalost od 2,4\%, kod jednog fibrilacija atrija, učestalost fibrilacije atrija 1,2 \%, a kod drugog AV blok II. stupnja, učestalost AV bloka II. stupnja je 1,2 \%. Kako je AV blok II stupnja jedina ustvrđena fiziološka aritmija tako je i učestalost fizioloških aritmija identična učestalosti AV bloka II stupnja, 1,2 \%.

AV blok drugog stupnja ubrajamo u fiziološke aritmije i u literaturi je njegova učestalost znatno veća i kreće se oko $20 \%$ (Patteson, 1996.) za razliku od ovdje zabilježenih 1,2 \%. Tako nisku frekvenciju AV bloka, kao najčešće vagusom inducirane poremetnje $u$ ritmu (Radostits i sur., 2007.) te potpuni izostanak bilo koje druge fiziološke aritmije je $\mathrm{u}$ potpunosti suprotno od dosada objavljenih podataka. U radu iz 2010. objavljen je podatak o potpunom izostanku AV bloka drugog stupnja u kurdskih konja, ali je kod njih učestalost drugih fizioloških aritmija (sinusna aritmija, wandering pacemaker, i SA blok) izrazito visoka (44,4 \%). Fregin također nije pronašao AV blok II stupnja u američkog kasača (Fregin, 1982.).

Učestalost fibrilacije atrija od 1,2\% sukladna je podatcima iz literature i koja 
se prema različitim autorima kreća od 0,23 do $2,5 \%$.

Izrazito nisku učestalost fizioloških aritmija, odnosno izostanak bilo koje druge fiziološke aritmije osim jednog slučaja AV bloka II stupnja, $\mathrm{u}$ hrvatskih pasmina konja smatram posljedicom uzbuđenja tijekom snimanja elektrokardiograma i njemu posljedičnog povišenja tonusa vagusa.

Frekvencija srca u mirovanju se smatra mjerom za fizičku kondiciju životinje i dobar je pokazatelj zdravlja kardiovaskularnog sustava. U literaturi se navode rasponi frekvencije srca (pulsa) od 26-46 s prosjekom od 36 otkucaja u min. za engleske punokrvnjake i 26-50 s prosjekom od 34,8 otkucaja u min za američke kasače (Fregin, 1982.), 20-49 $\mathrm{s}$ prosjekom od 34,2 otkucaja u min za Turkman konje (Alidadi i sur., 2002.), za kurdske konje se navodi raspon 23-45 s prosjekom od 32,3 otkucaja (Tavanei-Manesh i Dalir-Naghadeh, 2010.); Santarosa i sur. (2016.) navode frekvenciju od 56,7 $\pm 1,7$ u američkog minijaturnog konja; Shade i sur. (2014.) $\mathrm{u}$ crioulo konja navode prosječnu srčanu frekvenciju 43,6 $\pm 11,6$; Paslavska i sur. (2018.) navode frekvenciju 39 $\pm 8,1$ u salesijskog konja, dok u poljskih angloarapskih polukrvnjaka navode frekvenciju 43,83 \pm 10 (Paslawska i sur., 2012.). U ovoj je studiji raspon frekvencije srca bio između 28 i 90 otkucaja u min. s prosječnom vrijednošću od 52,89 $( \pm 12,73)$ otkucaja u min. što je znatno više od bilo koje od objavljenih vrijednost za konje do sada. Ovako visoke vrijednosti srčane frekvencije smatramo posljedicom uzbuđenosti životinja kod snimanja elektrokardiograma, što predstavlja veliki problem pri snimanju ambulantnog elektrokardiograma. Obje istraživane pasmine vrlo specifične po pitanju svakodnevnog kontakta i manipulacije. Posavski konji imaju svakodnevni minimalan kontakt s čovjekom, gotovo isključivo u vrijeme hranjenja pa dolazak čovjeka u staju ili izvođenje životinje imaju za posljedicu uzbuđenje životinje i povišenje srčane frekvencije. Konji lipicanske pasmine su po prirodi vrlo temperamentni i sve životinje uključene u ovo istraživanje su sportski konji koji također dolaskom čovjeka u staju ili izvođenjem postaju izrazito uzbuđeni. U veterinarskoj medicini u Hrvatskoj dobar dio pacijenata su upravo ovakvi konji, koji nisu navikli na opušteni kontakt s čovjekom i koji redovito na bilo kakvu manipulaciju ili običan klinički pregled i postavljanje elektroda za snimanje EKG-a reagiraju znatnim povećanjem srčane frekvencije. Nameće se zaključak da bi svakoj životinji koja ima povišenu frekvenciju srca u mirovanju trebalo snimiti Holter EKG, u vremenu od nekoliko sati, Raekalio preporuča snimanje noću, u potpunom odsustvu čovjeka iz staje (Raekalio, 1992.). Scheffer (1995.) je u studiji u kojoj uspoređuje srčanu frekvenciju zabilježenu Holter monitorom kroz 22 sata prijavljuje raspon od $31 \pm 2$ do $138 \pm 11$ udaraca $\mathrm{u}$ minuti $\mathrm{u}$ mirovanju, $\mathrm{i}$ frekvenciju od $79 \pm 8$ do $177 \pm 12$ pod opterećenjem. Ukoliko usporedimo raspon frekvencija $\mathrm{u}$ ovom istraživanju $\mathrm{s}$ rezultatima iz gore spomenute studije, nalazimo da su konji iz ove studije $u$ nešto užem i nižem rasponu. U ženskih je životinja

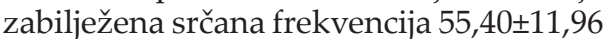
dok je u muških zabilježena frekvencija 49,35 $\pm 13,11$; razlika između ove dvije vrijednosti je statistički značajna $(P<0,05)$. Nisu ustvrđene statistički značajne razlike između srčanih frekvencija konja različite dobi.

\section{Literatura}

1. ALIDADI, N., M. R. M. DEZFOULI, M. G NADALIAN, A. REZAKHANI and I. NOUROOZIAN (2002): The ECG of the Turkman horse using the standard lead base apex. J. Equine Vet. Sci. 22, 182-184.

2. AMADA, A. and H. KURITA (1975): Five cases of paroxysmal atrial fibrillation in the race horse. Exp. Rep. Equine Hlth. Lab. 12, 89-100. 
3. BEGLINGER, R., R. PFISTER and K. HEIDER (1980): Herz- und Kreislaufdiagnostik beim Pferd im Institut fur Veterinar-Physiologie (Direktor: Prof. Dr. Dr.h.c. H. Sporri) der Universitat Zurich. Schweiz Arc. Tierheilk. 122, 533-539.

4. BROIJMANS, A. W. M. (1957): Electrocardiography in the horses and cattle: theoretical and clinical aspects. Rijksuniversiteit te Utrecht. Utrecht.

5. BUCHAN, J. W. (1965): Spontaneus arrhythmias and cinduction disturbances in domestic animals. Ann N Y Acad Sci. 127, 224-238.

6. DEEM, D. A. and G. F. FREGIN (1982): Atril fibrillation in horses, a review of 106 clinical cases, with consideration of prevalence, clinical signs and prognosis. JAVMA 180, 261-265.

7. FREGIN, G. F. (1982): The cardiovascular system. In: Mansmann, R. A.: Equine medicine and surgery $3^{\text {rd }}$ edition. American Veterinary publications INC, Santa Barbara (645-704).

8. GLAZIER, D. B. and H. H. DUKES (1963): Atrial premature beats in a horse. Irish Vet. J. 17, 87-88.

9. GLENDING, E. S. A, (1972): Significance of clinical abnormalities of the heart in soundness. Equine Vet. J. 4, 21-26.

10. GUYTON, A. C. and J. E. HALL (2006): Heart Muscle; The Heart as a Pump and Function of the Heart Valves. In: Guyton, A. C. and Hall, J. E.: Textbook of medical physiology. Saunders Elsevier, Philadelphia (103-115).

11. HAMLIN R. A., W. L. KLEPINGER, K. W. GLIPIN and C. R. SMITH (1972): Autonomic control of heart rate in the horse. Am. J. Physiol. 222, 976-978.

12. HOLMES, J. R. (1963): Clinical examination of the equine heart. Proc $17^{\text {th }}$ Int. Vet. Cong. 2, 1195-1199.

13. HOLMES, J. R. and B. J. ALPS (1966): Observations on partial atrio-ventricular heart block in the horse. Can. Vet. J. 7, 280-290.

14. HOLMES, J. R. and B. J. ALPS (1969): The effect of exercise on rhythm irregularities in the horse. Vet. Rec. 78, 672-683.

15. HOLMES, J. R. (1974): An investigation of cardiac rhythm using an on-line radiotelemetry/computer link. J Sth Afr Vet Assoc. 45, 251-261.

16. HOLMES, J. R. (1980): Cardiac rhythm irregularities in the horse. In Practice 2, 15-25.

17. HOLMES, J. R. (1984): Equine electrocardiography, some practical hints on technique. Equine Vet. J. 16, 477-479.

18. KIRYU, K., M. KANEKO, T. KANEMARU, T. YOSHIHARA, M. HASEGAWA and Y. MTOMIOKA (1985): Cardiopathology of sinoatrial block in horses. Jpn. J. Vet. Sci. 47, 45-54.

19. KRUZ, N. G., R. J. ROSE and D. R. HODGSON (2000): Cardiovascular system. In: Rose, R. J., Hodgson D. R.: Manual of equine practice. Saunders. Philadelphia (237-273).

20. MARR, C. M. (1997): Treatment of arrhythmias and cardiac failure. In: Robinson, N. E.: Current Therapy in Equine Medicine. WB Saunders, Philadelphia (250-259).
21. MENZIES-GOW, N. (2001): ECG interpretation in the horse. In Practice 23, 454-459.

22. MILLER, P. J. and J. R. HOLMES (1983): Effect of cardiac arrhythmia on left ventricular and aortic blood pressure parameters in the horse. Res. Vet. Sci. 35, 190-199.

23. NATTEL, S., A. MAGUY, S. LE BOUTER and Y.H. YEH (2007): Arrhythmogenic Ion-Channel Remodeling in the Heart: Heart Failure, Myocardial Infarction, and Atrial Fibrillation. Physiol. Rev. 87, 425-456.

24. OHMURA, H., A. HIRAGA, T. TAKAHASHI, M. KAI and J. H. JONES (2003): Risk factors for atrial fibrillation during racing in slow-finishing horses. J. Am. Vet. Med. Assoc. 223, 84-88.

25. PASLAWSKA, U., R. PASLAWSKI, A. NOSZCZYKNOWAK, K. MICHLIK and J. NICPON (2012): Physiological ecg value for polish half-bred angloarab horses. Bull Vet. Inst. Pulawy 56, 631-635.

26. PASLAWSKA, U., K. MICHLIK, I. JANUS, R. PASLAWSKI, D. ZYSKO and A. NOSZCZYKNOWAK (2018): Physiological values of ECG parameters in Silesian horses. Med. Weter. 74, 577580.

27. PATTESON, M. W. (1996): Equine Cardiology. Blackwell Science. Oxford. pp. 254-255.

28. PHYSICK-SHEARD, P. W. (1999a): Electrocardiography. In: Colahan, P. T.: Equine medicine and surgery. Mosby, St. Louis (314-318).

29. PHYSICK-SHEARD, P.W.(1999b): Pathophysiology and principles of therapy. In: Colahan, P. T.: Equine medicine and surgery. Mosby, St. Louis (337-380).

30. PHYSICK-SHEARD, P. W. (1999c): Examination of the cardiovascular system. In: Colahan, P. T. Equine medicine and surgery. Mosby, St. Louis (296-314).

31. RADOSTITS, O. M., C. GAY, K. W. HINCHCLIFF and P. CONSTABLE (2007): Diseases Associated with Nutritional Deficiencies. In: Radostits, O. M.: Veterinary medicine $10^{\text {th }}$ ed. W.B. Saunders Elsevier, USA (1477-1556).

32. RAEKALLIO, M. (1992): Long term ECG recording with Holter monitoring in clinically healthy horses. Acta Vet. Scand. 33, 71-75.

33. REEF, V. B., E. S. CLARK, J. A. OLIVER and W. J. DONAWICK (1986): Implantation of a permanent transvenous pacing catheter in a horse with complete heart block and syncope. J. Am. Vet. Med. Assoc. 189, 449-452.

34. REEF, V. B. and C. M. MARR (2010): Dysrhythmias: assessment and medical management. In: Marr, C. M.: Cardiology of the horse $2^{\text {nd }}$ edition. Saunders, London (159-178).

35. REZAKHANI, A. (1975): Equine electrocardiography. J. S. Afr. Vet. Assoc. 46, 207.

36. SAMPSON, S. N., R. L. TUCKER and W. M. BAYLY (1999): Relationship between VO2 max, heart score and echocardiographic measurements obtained at rest and immediately following maximal exercise in Thoroughbred horses. Equine Vet. J. Suppl. 30, 190-194. 
37. SANTAROSA, B. P., M. L. G. LOURENCO, G. N. DANTAS, C. M. V. ULIAN, M. C. T. HECKLER, M. J. SUDANO, R. C. GONCALVES and S. B. CHIACCHIO (2016): Electrocardiographic parameters of the American Miniature Horse: influence of age and sex. Pesq. Vet. Bras. 36, 551-558.

38. SCHEFFER, C. W., J. H. ROBBEN and M. M. SLOET VAN OLDRUITENBORGH-OOSTERBAAN (1995): Continuous monitoring of ECG in horses at rest and during exercise. Vet. Rec. 137, 371-374.

39. SCHADE, J., M. F. S. SCHADE and J. H. FONTEQUE (2014): Auscultatory and electrocardiographic characteristics of Crioulo horses. Pesq. Vet. Bras. 34, 281-289.

40. TAVANAEI-MANESH, H. and B. DALIRNAGHADEH (2010): Electrocardiographic parameters in purebred Kurd horse. J. Anim. Vet. Adv. 9, 2698-2703.
41. TOO, K. (1960): Abnormal electrocardiograms in the horse. Jpn. J. Vet. Res. 8, 29-34.

42. VAN LOON, G. and M. PATTESON (2010): Electrophysiology and arrhythmogenesis. In: Marr, C. M.: Cardiology of the horse $2^{\text {nd }}$ edition. Saunders Elsevier, Edinbourgh (59-73).

43. VIBE-PETERSEN, G. and K. NIELSEN (1980): Electrocardiography in the horse (a report of findings in 138 horses). Nord. Vet. Med. 32, 105-121.

44. WATSABAUGH, C. J. (1963): Second degree heart block in the horse. Ohio State University. Columbus, Ohio.

45. WATSABAUGH, C. J., C. R. SMITH, R. L. HAMLIN and D. L. SMETZER (1964): Second degree atrioventricular block in the horse. Physiologist 7, 280.

46. WITZEL, D. A., L. A. GEDDES, H. E. HOFF and J. MCFARLANE (1968): Electrical defibrillation of the equine heart. Am. J. Vet. Res. 29, 1279-1285.

\section{ECG in Croatian posavac and Lipizzan horse - frequency and rythm}

Darko GRDEN, DVM, PhD, Expert Associate, Jelena GOTIĆ, DVM, PhD, Assistant Professor, Iva ŠMIT, DVM, PhD, Assistant Professor, Martina CRNOGAJ, DVM, PhD, Assistant Professor, Nika BRKLJAČA BOTTEGARO, DVM, PhD, Assistant Professor, Karol ŠIMONJI, DVM, Expert Associate, Dora IVŠIĆ ŠKODA, Mag. Med. Biochem., Blanka BEER LJUBIĆ, Mag. Med. Biochem., PhD, Nada KUČER, DVM, PhD, Associate Professor, Faculty of Veterinary Medicine University of Zagreb, Croatia

ECG is old but still irreplaceable diagnostic tool in cardiology. It has been used for almost a century and despite of its age still there are no alternative diagnostic tools in sight. It is standardised and routinely used in equine medicine, but lately a question of breed specific references has appeared and new research has been done in order to explore the need for breed specific reference values. No research, up to our knowledge, has been done on Croatian posavac and Lipizan horse ECG. The aim of this study was to determine standard reference values for heart rate and the prevalence of arrhythmias in Lipizzaner and Croatian posavac horse. The study included 82 healthy horses of different age and sex, 32 Lipizzaner and 50 Croatian posavac horses. Electrocardiograms were recorded for duration of 5 minutes in base-apex lead. The heart rate, rhythm and arrhythmia were determined from the recorded ECGs. The mean heart rate $( \pm S D)$ of all the horses included in this study was $52.9( \pm 12.7)$ beats per minute, which is significantly higher than any published for the horses till now. The incidence of arrhythmias was $2.4 \%$. High heart rate and low incidence of heart arrhythmias can be a breed characteristic, but we believe that they are in fact a consequence of ambulatory ECG recording that may not be the best choice for ECG analysis in horses. As reported heart rates in our study were high, much higher than any reported for horses at rest, that is why we believe that proper ECG for analysis in horses should be taken in familiar peaceful environment. We believe that further research into equine ECG it is warranted, this time a 24 hour Holter ECG should be recorded.

Key words: Lipizzaner; Croatian Posavac horse; ECG; Arrhythmias; Heart frequency 